УдК 676.81 .052

๑ О. О. Паламар, к.т.н., ст. викладач, Т. В. Слобода, здобувач, Н. М. Кандяк, К.т.н., асистент, УАД, Львів, Україна

\title{
ЕКСПЕРИМЕНТАЛЬНІ ДОСЛІДЖЕННЯ ЗУСИЛЬ ВИГОТОВЛЕННЯ КОНТУРІВ РОЗГОРТОК КАРТОННИХ ПАКОВАНЬ МЕТОДОМ НОЖИЧНОГО РІЗАННЯ
}

Проведено експериментальні дослідження способу виготовлення картонних розгорток методом ножичного різання. За результатами експериментів обґрунтовано зменшення технологічних зусиль завдяки виникненню руйнівних напружень зрізу, що на порядок менші від напружень стиску, які виникають при висіканні. Розроблено рекомендації щодо вибору зазору між ножами залежно від товщини картону за умови мінімізації лінійних зусиль та забезпечення необхідної якості виготовлення контуру картонної розгортки.

Ключові слова: експериментальний стенд, лінійне зусилля, ножичне різання, розгортка картонного паковання, ніж.

Постановка проблеми

Експериментальні дослідження технологічних зусиль, що виникають під час виготовлення контурів розгорток картонних паковань - один із ключових етапів на шляху створення відповідного обладнання, оскільки це дає можливість кількісно оцінити вплив різних чинників на лінійне зусилля різання та якість утвореного контуру картонної розгортки. Тільки комплексний аналіз процесу різання уможливлює розроблення рекомендацій щодо вибору технологічних та геометричних параметрів процесу різання.

\section{Аналіз попередніх} досліджень

Аналіз літературних джерел [1-3] показав відсутність систематизованої методики прове-

\footnotetext{
(c) $2014 \mathrm{p}$.
}

дення експериментальних досліджень для визначення лінійних зусиль виготовлення картонних розгорток. У роботі [1] при дослідженні зусилля висікання, не враховано вплив ежекторного матеріалу на загальне технологічне зусилля висікання, що унеможливлює комплексно оцінити процес штанцювання. Автор [2] у своїй роботі не розкриває послідовність процесу проведення експериментальних досліджень, а наводить емпіричні формули без встановлення рекомендацій щодо вибору геометричних чи технологічних параметрів штанцювання. Автор [3] встановив порівняльні характеристики руйнування картону при ножовому та ножичному способі розділення матеріалу, але характер зміни технологічних зусиль провів лише для 
висікання розгорток картонних паковань.

\section{Мета роботи}

Розроблення методики проведення досліджень способу виготовлення розгорток картонних паковань методом ножичного різання та оцінка впливу на кількісні та якісні показники процесу технологічних параметрів.

\section{Результати проведених осліджень}

Для досліджень на кафедрі поліграфічних і пакувальних машин та технології пакування УАД було виготовлено експериментальний стенд, кінематична схема якого зображена на рис. 1.

Стенд складається із привода, механізму привода штанцформи та вимірювальної секції, які встановлені на станині 1. Привод механізму здійснюється від електродвигуна 2, який через муфту 3, черв'ячний редуктор 4 з передатнім числом $\mathrm{u}=22$ та однообертову муфту 5 приводить в рух вал 6. Під час увімкнення однообертова муфта 5 з'єднує вихідний вал редуктора 3 з приводним валом 6 механізму привода штанцформи на один оберт. Вал 6, на якому закріплений кривошип 7 через регульовану тягу 8 приводить у коливний рух коромисло 9. Зворотньо-поступальний рух штанцформи 11 з вимірювальним пристроєм 12 і штоком 13 здійснює коромисло 9 через шатун 10. Формування ліній зрізу відбувається при взаємодії верхнього рухомого ножа 14 із нижнім нерухомим ножем 14.' у стенді передбачено регулюван- ня величини зазору між крайками лез ножів переміщенням їх у горизонтальній площині регулювальним гвинтом для зміни величини зазору. Для балансування механізму передбачено противагу 15.

Для вимірювання технологічних зусиль, що виникають при ножичному різанні картонних заготовок, застосовується метод, що полягає у перетворенні лінійних деформацій активних елементів (датчиків) у електричний сигнал. У якості датчиків застосовуються тензорезистори.

В основі принципу дії тензорезисторів лежить явище тензоефекту, що полягає в зміні електричного опору провідників і напівпровідників при їхній механічній деформації. Тензорезистори з'єднані за мостовою схемою (рис. 2) електричних опорів. Умова рівноваги моста $\mathrm{R} 1 \cdot \mathrm{R} 3=\mathrm{R} 2 \cdot \mathrm{R} 4$. При проведенні досліджень на діагональ ab мостика подають живлення, а 3 діагоналі cd - знімають сигнал, значення якого залежить від розбалансування контуру, що спричиняється зміною опору тензорезисторів під дією механічної деформації від технологічних зусиль.

Програмою експериментальних досліджень передбачалось оцінити вплив виду картону, його товщини та напрямку розташування волокон, величини зазору між ножами, кутів загострення ножа та контрножа на величину технологічних зусиль, характер їх зміни під час різання, а також візуальне оцінювання якості зрізу контуру картонної розгортки. 


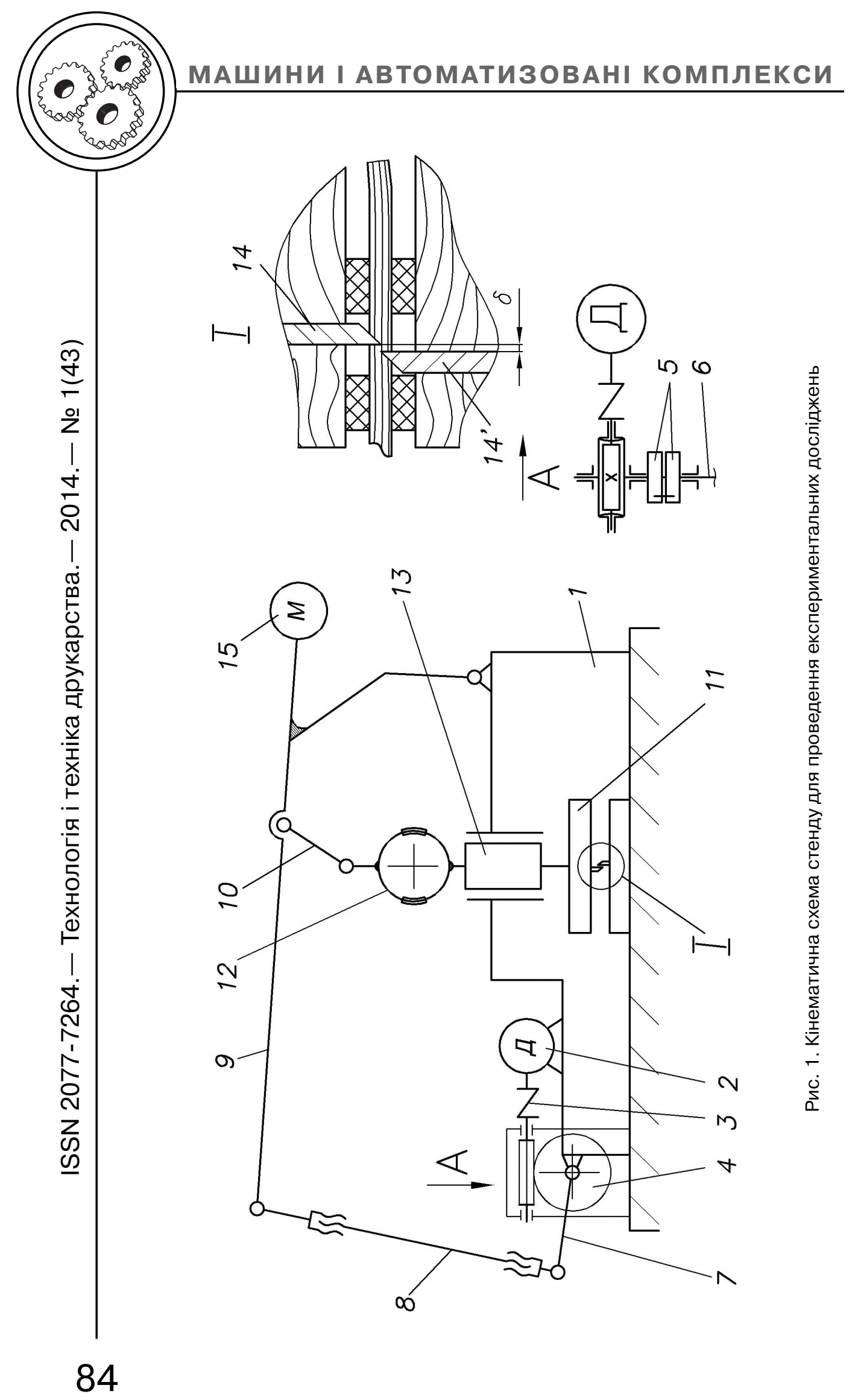




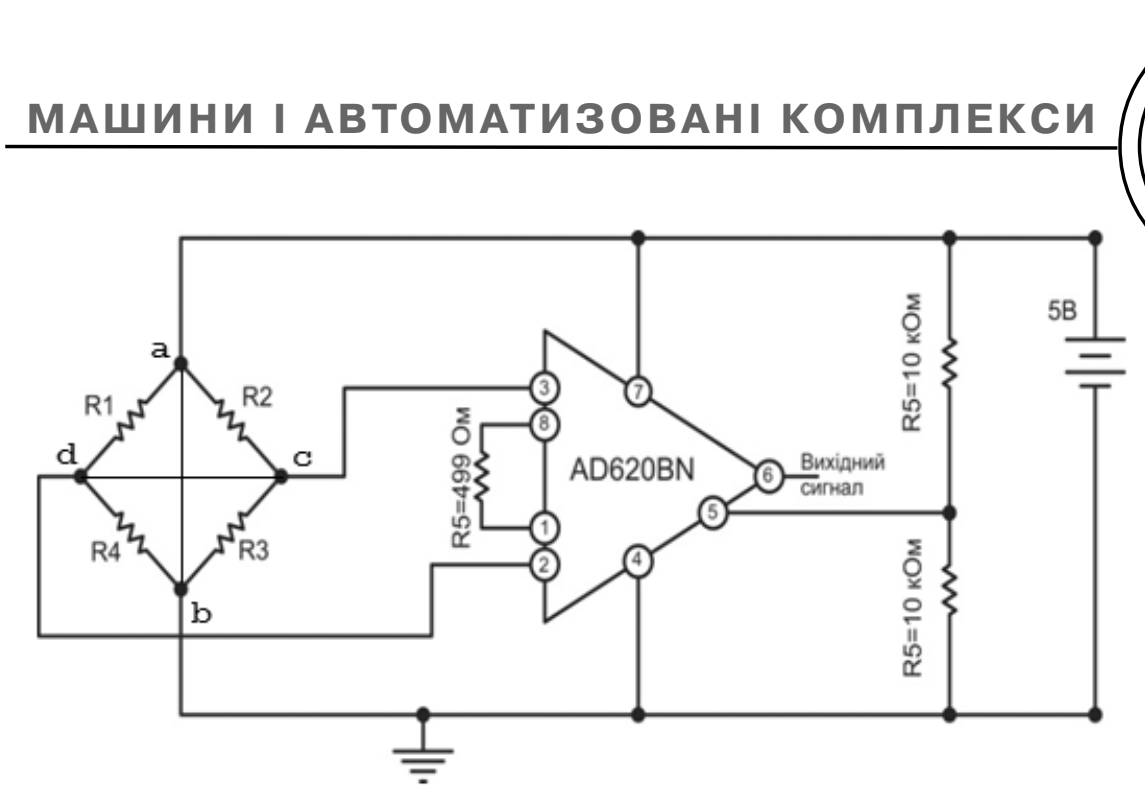

Рис. 2. Схема під'єднання тензорезисторів

Для експериментальних досліджень використано п'ять типів картону:

- тип I - картон хром-ерзац макулатурний крейдований, марка МО, товщина $\Delta=0,3$ мм, мaca $1 \mathrm{~m}^{2}-240$ г;

- тип II - картон хром-ерзац макулатурний некрейдований, марка $\mathrm{H}$, товщина $\Delta=0,4 \mathrm{Mm}$, мaca $1 \mathrm{~m}^{2}-300$ г;

- тип III - картон макулатурний коробковий, марка НМ, товщина $\Delta=0,5 \mathrm{Mm}$, маса $1 \mathrm{~m}^{2}-$ 370 г;

- тип IV - картон хром-ерзац, макулатурний некрейдований марка $\mathrm{H}$, товщина $\Delta=$ = 0,6 мм, маса $1 \mathrm{~m}^{2}-420$ г;

- тип V - картон хром-ерзац макулатурний крейдований, марка МО, товщина $\Delta=0,7 \mathrm{MM}$, мaca $1 \mathrm{~m}^{2}-520$ г.

Результати експериментальних досліджень залежності величини лінійного зусилля від товщини картону та напрямку розташування волокон зображені на рис. 3.

Даний графік відображає вплив товщини картону на лінійне зусилля у повздовжньо- му та поперечному напрямку розташування волокон. Із графіка можна зробити наступні висновки:

- із збільшенням товщини картону лінійне зусилля різання зростає як у повздовжньому так і у поперечному напрямку розташування волокон;

— лінійне зусилля при ножичному різанні у 3 рази менше ніж при висіканні [4], що зумовлено заміною руйнування волокон картону напруженнями зрізу, які на порядок менші за напруження стиску, котрі виникають при висіканні;

- крива залежності лінійних зусиль при ножичному різанні носить нелінійний характер і якісно збігається із кривою залежності лінійних зусиль від товщини картону при висіканні [4];

- лінійні зусилля при поперечному розташування волокон більші від зусиль при повздовжньому розташуванні волокон в середньому на $30 \%$.

При дослідженні величини лінійного зусилля q різання картонних розгорток методом ножичного різання важливими є не 


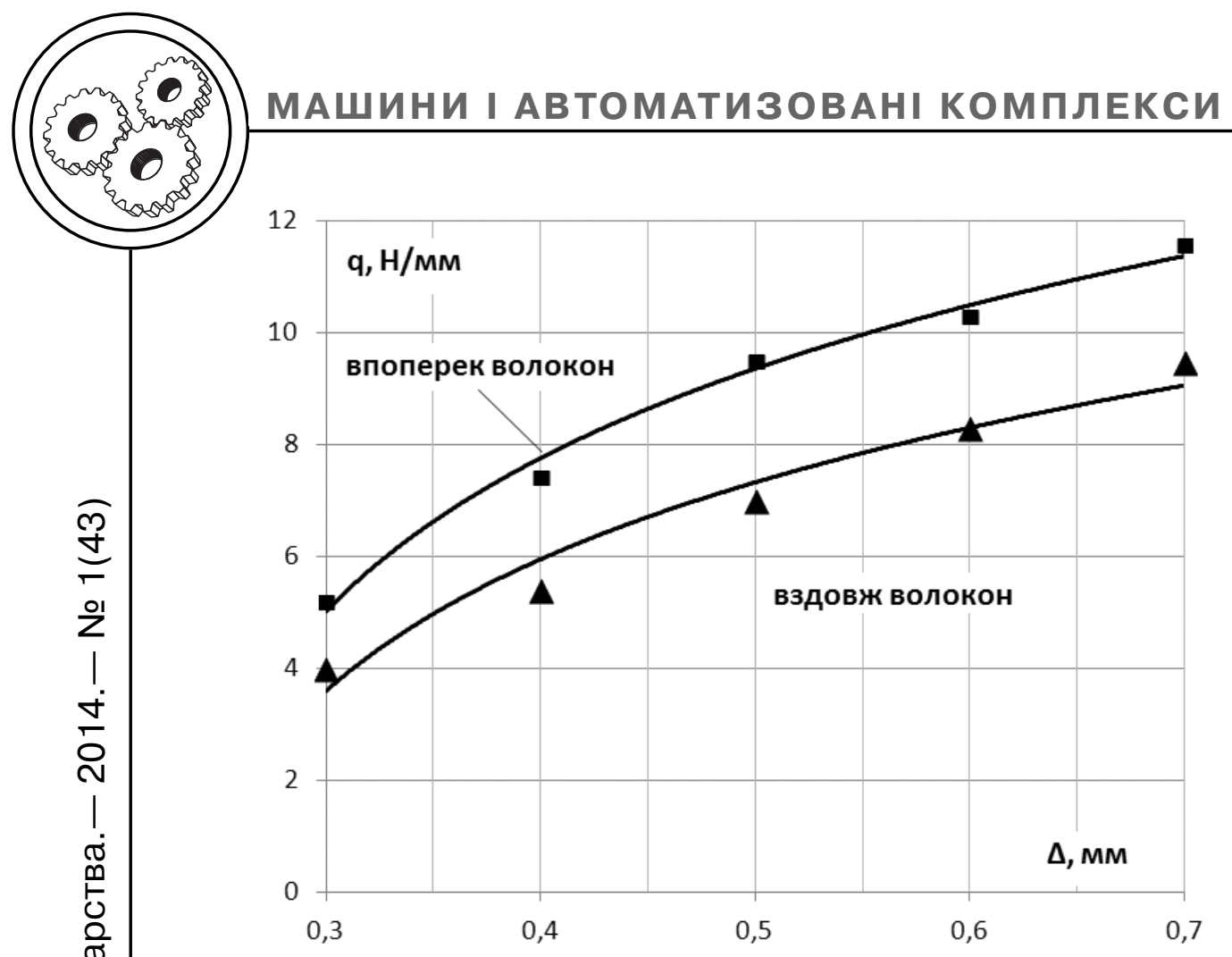

Рис. 3. Залежність лінійного зусилля від товщини картону

лише кількісні показники, але й якісні, а саме характер переміщення $\mathrm{h}$ різального інструмента (рис. 4).

Аналіз отриманого запису кривої підтверджує припущення [3], що процес виготовлення картонних розгорток способом ножичного різання складається із попереднього стиску картонної розгортки та ї̈ зрізу. Криву доцільно поділити на ділянки: Ділянка «А-В» - відповідає холостому ходу верхнього різального інструменту; на ділянці «B-C»- спостерігається виникнення напружень стиску за рахунок контакту верхніх та нижніх ежекторних подушок із картоном; на ділянці «C-D-E» відбувається зріз волокон картону за рахунок перекриття різального інструменту. Паралельно на ділянці «C-E-F» продовжується стиск ежектор- них подушок; на ділянці «F-G»картон вже розрізаний і залишаються тільки напруження стиску від ежекторного матеріалу; ділянка «G-H» - відповідає холостому зворотному ходу верхнього різального інструменту.

\section{Висновки}

1. Проведені дослідження підтвердили дієздатність способу виготовлення картонних розгорток методом ножичного різання.

2. Результати експериментальних досліджень лінійних зусиль при ножичному різанні показали їх зменшення у 3 рази порівняно із висіканням, що пояснюється виникненням напружень зрізу, котрі на порядок менші від напружень стиску, що виникають при висіканні.

3. Розроблено рекомендації щодо вибору оптимального 


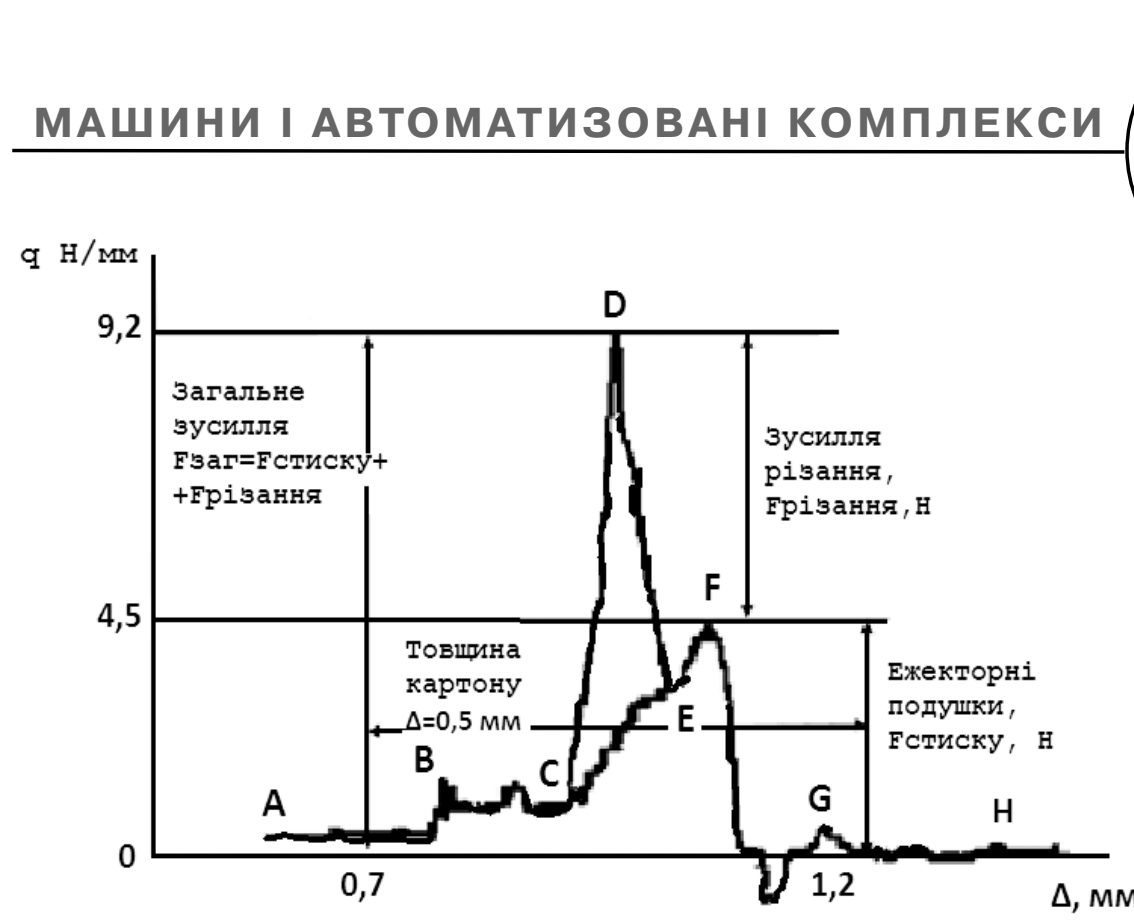

Рис. 4. Залежність лінійного зусилля від переміщення різального інструмента

зазору $\delta$ між різальними інструментами, виходячи з умови мінімізації зусиль та забезпечення необхідної якості, який повинен становити $\delta \approx 0,3$ товщини $\Delta$ картону.

4. Аналіз характеру зміни технологічного зусилля підтвер- джує тезу щодо виникнення при ножичному різанні напружень зрізу, що спричиняє зменшення лінійних зусиль.

5. Візуальна оцінка контурів картонної розгортки задовольняє вимоги щодо якості зрізу.

\section{Список використаної літератури}

1. Терницький С. В. Дослідження технологічно-необхідних зусиль висікання розгорток картонних паковань / С. В. Терницький // Упаковка : Журнал для виробників та споживачів тари і упаковки. - 2011. - № 3. C. 28-31.

2. Банах Ю. О. Технологічні навантаження в процесі штанцювання та шляхи їх зменшення / Ю. О. Банах // Поліграфія і видавнича справа. - Л. : УАД, 1997. — № 32. - С. 67-70.

3. Задра В. М. Комплексна оптимізація засобів для прорізування різнопрофільних отворів у паперово-картонних виробах: дис. ...канд. техн. наук : 05.05.01 / Задра Володимир Михайлович. - Львів, 2003. - 177 с.

4. Хведчин Ю. Й. Брошурувально-палітурне устаткування. Розрахунки виконавчих механізмів : навч. посіб. / Ю. Й. Хведчин, О. Б. Книш, А. Б. Коломієць. - Львів : УАД, 2010. - 128 с.

5. Пат. 98851 Україна, МПК В 31 В 1/16, В 26 F 1/38. Спосіб виготовлення розгорток картонного паковання та пристрій для його реалізації / РегейІ. І., Книш О. Б., Млинко О. І., Слобода Т. В. - № а201011741 ; заявл. 04.10.2010 ; опубл. 25.06.2012, Бюл. № 12. - 4 с. : іл. 


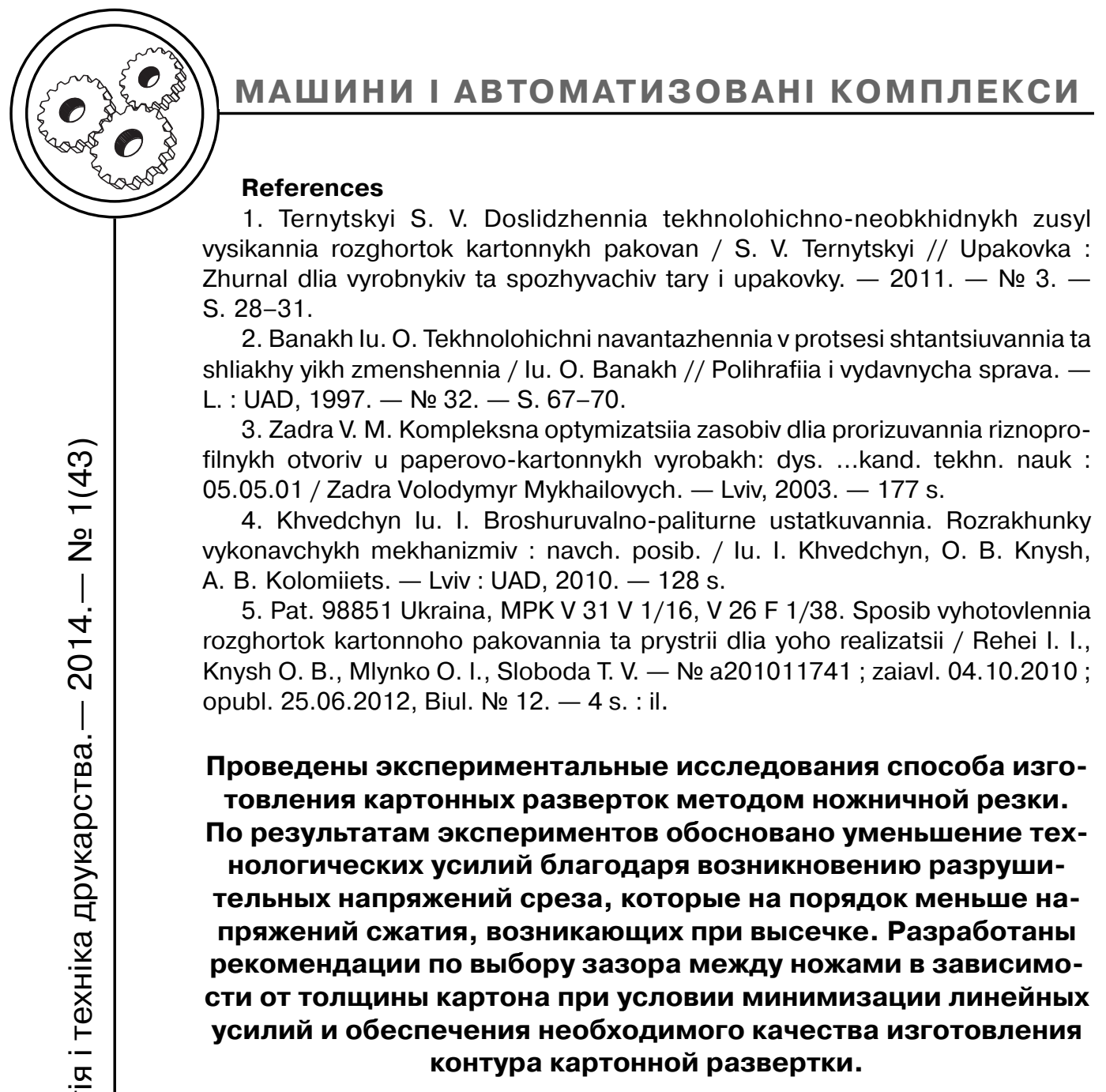

Ключевые слова: экспериментальный стенд, линейное усилие, ножевое резание, развертка картонной упаковки, нож.

Conduct experimental research of cardboard sweep share design during knife cutting process. The experimental results justified the reduction of technological efforts caused by destructive shear tension which is less than compressive tension arising from the die-cutting. The advice concerning the choice of blades gap width depending on the cardboard thickness in terms of minimal linear efforts have been offered to ensure the necessary quality of cardboard sweep share design.

Keywords: the experimental stand, the linear efforts, knife cutting process, cardboard sweep share, knife. 